\title{
Dynamics to Enhance the Conservation of Locally Threatened Medicinal Plant Species (Maerua Oblongifolia) Through Phytochemical Analysis and Antibacterial Study
}

Mathewos Agize Ante ( $\square$ mathewosagize@yahoo.com )

WSU: Wolaita Sodo University

Zemede Asfaw Woldemariam

Addis Ababa University College of Natural Sciences

Sileshi Nemomissa Duguma

Addis Ababa University College of Natural Sciences

Tizazu Gebre Alemayehu

Arba Minch University

Mathewos Anza Alemu

WSU: Wolaita Sodo University

Tizita Lema Bergene

WSU: Wolaita Sodo University

Mintiwab Abrham Dana

WSU: Wolaita Sodo University

Research

Keywords: Antibacterial activity, conservation, Maerua oblongifolia, phytochemical analysis

Posted Date: August 5th, 2021

DOI: https://doi.org/10.21203/rs.3.rs-757527/v1

License: (c) (1) This work is licensed under a Creative Commons Attribution 4.0 International License.

Read Full License 


\section{Abstract}

Introduction: For generations, many plants were extracted to find drugs and to discover novel and new chemical structures from extracts. Maerua oblongifolia (Forsk.) A. Rich, "Sangganaa" in Dawuro language is a locally threatened traditional medicinal plant, which is traditionally used to treat diarrhea. The present study aimed to check the chemical contents of the different plant parts for possible shifting of the extensive use of the root to other parts of the plant.

Methods: Phytochemical screening tests were carried out by standard procedures to investigate various classes of secondary metabolites. Roots, root bark, stem bark, and leaves were extracted by maceration in aqueous and ethanol to get crude extracts. Antibacterial effect of extracts against Escherichia coli and Salmonella thypi was evaluated by the disc diffusion method.

Results: The phytochemical analysis showed the presence of alkaloids, saponins, tannins, phenols, carbohydrates, and proteins in the tested parts of the plant. Antibacterial activity displayed the extracts of M. oblongifolia against tested bacteria strains in dose dependent manner. Among tested extracts, roots and stem barks ethanol extracts showed potential antibacterial activity, with zone of inhibitions (19.0 \pm $1.15,17.0 \pm 1.00)$ in $100 \mathrm{mg} / \mathrm{mL}$, and $(17.3 \pm 0.57,15.0 \pm 1.00)$ in $50 \mathrm{mg} / \mathrm{mL}$, respectively.

Conclusion: The finding showed a possibility to shift stem bark instead of roots in the use of traditional medicinal practices to ensure conservation and sustainable use of Maerua oblongifolia. The finding also supports the traditional use of the plant's root or stem bark for the treatment of diarrhea.

\section{Introduction}

For generations, many plants were investigated to find new drugs and combat drug-resistant microbials and the appearance of undesirable side effects of antibiotics. In this way, the search for new antimicrobial agents and the discovery of novel chemical structures from plant extracts has continued. Phytochemical screening of traditional medicinal plants is very important in identifying new sources of new natural products for drugs (Savithramma et al., 2011). Around 80\% of the plant products discovered to date are said to be of plant origin and their the annual market for herbal products had sales exceeded the US $\$ 65$ billion (Savithramma et al., 2011; Sasi et al., 2020). The global herbal medicine market size was estimated to be US\$ 83 billion in 2019 and is expected to reach US\$ 550 billion by 2030 at a CAGR of $18.9 \%$ through 2030 (InsightSLICE, 2021).

On the other hand, practices focused on individual species encourage the sustainability of only the targeted medicinal plants. This, in turn, causes the emergence of drug-resistant microbes' or the loss of neglected medicinal plants. Consequently, this urges searching for indigenous knowledge and other plants tied/linked with the same information. In another facet, searching for a drug and earning huge money by selling processed and raw resources of medicinal plants are posing constraints to the conservation efforts of threatened medicinal plants. Though the traditional uses of the plants of the area reconfirmed during 
the preliminary ethnobotanical field study were documented, the quality and quantity of the phytochemicals are yet to be scientifically validated.

Laboratory work targeting conservation was initiated in this study as follow-on from the results of ethnobotanical field study and information analysis undertaken in Dawuro Zone of Southwestern Ethiopia. Of the plants used and reported medicinal, Maerua oblongifolia (Forsk.) A. Rich. (Capparaceae) locally known as "Sangganaa" in Dawuro language, was one of the most widely used medicinal plants. It was among other medicinal plants extensively used in the traditional herbal healing system in Dawuro for the treatment of both human and domestic animals in addition to serving as detergent for washing purposes (Agize et al., 2013; Ekero et al., 2018).

Maerua oblongifolia (Forsk.) A. Rich (Capparaceae) is a woody shrub/tree plant. Its traditional use of root part was known in the study area for generations (Agize et al., 2013). This part was pounded; chewed; administered as dry bath, and taken either with other plants or alone in the form of drink; smoke (except for pregnant women) orally, nasally or anally. Traditionally, they use this plant's root to treat anthrax, stomachache, severe abdominal cramp, hook worm, body swelling, mump, tetanus, eye disease, liver cirrhosis, gonorrhea, meningitis and for different disease of both humans and cattle (Agize et al., 2013; Ekero et al., 2018). Most of the traditional medicinal use practice of the area has similarity with other areas. It was approved that the plant is used to cure various diseases such as fever, stomach ache, skin infections, urinary calculi, diabetes mellitus, epilepsy, pruritis, rigidity in lower limbs, and abdominal colic (Bhalakiya and Nainesh, 2019; Sasi et al., 2020); wound healing property (Arulanand et al., 2018; Sasi et al., 2020); for dog bite (Rady et al., 2019); to treat diabetes (Raju et al., 2014); for debility and aphrodisiac (Shodhganga, 2019); purifying the blood and to keep the body cool, diabetes and inflammatory diseases like arthritis (Santosh, 2019); as alternative tonic and stimulant (Revolvy, 2019); to treat Hypocholesterolaemia, malaria, abdominal pains and used as astringent (Mohamed et al., 2010); stomach ache and abdominal pains (Meragiaw, 2016) and act as alterative and energy stimulant (Savithramma, 2016).

It is indicated by local informants and herbalists that the species has been endangered in the area because of the widespread use of its root as a detergent, medicine, and for other purposes. Its growth in water stress areas, stony places of lowlands $300 \mathrm{~m}-1350 \mathrm{~m}$ above sea level (Kuria et al., 2017), unsustainable harvesting (Agize et al., 2013), and not domesticated being found only in the wild were also some of its threatened conditions. In general, the importance/relevance of this research work is justified since the species is locally threatened, the multiple uses that target material derived from the root part, harmful harvesting methods, and the variety of health problems traditionally treated by the remedy derived from it.

Thus, the activity was done to see whether the possibility to shift root use to other parts (root bark, stem bark and leaf) of the plant is plausible and worth considerations in future conservation efforts. In other word, the research attempted to check why knowledgeable persons focus on root rather than other parts i.e, to check the indigenous knowledge of using root because of the secondary metabolite found 
concentrated in the root or/and the continued use of this part because of acquisition from parents and others.

The study aimed at identifying the best strategy for conservation and sustainable utilization of the locally threatened traditional medicinal plant, $M$. oblongifolia, through an ethnobotanical knowledge-led phytochemical analysis and antimicrobial testing using extracts from its different parts.

\section{Materials And Methods \\ Preliminary Ethnobotanical Study}

The ethnobotanical information survey was conducted by using pre-prepared semi-structured individual interviews from September 2019 to April 2020. The sample size, 385 was determined following Cochran (1963) formula and snowball technique was used to find traditional medicinal plants practitioners for interviews. The semi-structured interview questions comprise traditional medicinal plants ailments/ disease treated, how they use, the habit, part and source of the plant from where they collect, and its conservation status following fore scholars (Martin, 1995; Cotton, 1996). Ethnobotanical knowledge on high fidelity level medicinal plants whose roots are known to have medicinal use value, collected from wild and locally threatened, was selected. One of these plants $M$. oblingifolia was informed that it is used to treat both human and domestic animals.

\section{Plant Material Collection}

Fresh leaf, root, root bark, and stem bark of $M$. oblongifolia were collected from its natural habitat of Dawuro, Southwest Ethiopia, from August 2020 to December 2020. Botanical identification of the plant was carried out using Ethiopia's flora and compared with voucher specimens at the National Herbarium of Ethiopia and authenticated by experts there. Finally, the identified triplet sample voucher specimen with voucher number MA0306/2020 was deposited there at the National Herbarium of Ethiopia at Addis Ababa University, Herbarium of Arba Minch University, and Mini-Herbarium of Dawuro Historical and Cultural Museum.

\section{Preparation of Plant Extracts}

The collected leaves, roots, root barks, and stem barks of M. oblongifolia were transported to Organic Chemistry Laboratory, Wolaita Sodo University, Ethiopia, and washed with tap water to remove unnecessary particles and external moisture wiped out with a dry cloth, and dried under shade at a room temperature. Briefly, the air dried plant materials were then carefully chopped, crushed, and pulverized into smaller fragments in mortar and pestle and finally ground into fine powder by using an electrical grinding mill.

Grounded powder of root, root bark, stem bark, and leaves of $150 \mathrm{~g}$ was extracted with distilled water (aqueous) and $99.8 \%$ ethanol by maceration separately, while shacking by electronic shaker at speed 230 rpm at room temperature for 24 hours. The solutions were filtered by suction filtration. The aqueous 
filtrates were suspended in the water bath at $60{ }^{\circ} \mathrm{C}$ at room temperature to concentrate a crude extract. The ethanol filtrates were concentrated by a vacuum rotary evaporator at $60^{\circ} \mathrm{C}$. Finally, the crude extracts were collected by labeled sterilized containers and kept under a deep freezer until further experiment (phytochemical analysis and antimicrobial activities testes).

\section{Phytochemical analysis of M. oblongifolia crude extracts}

Preliminary qualitative phytochemical analysis was carried out to detect the presence or absence of secondary metabolites in ethanol and aqueous leaf, stem bark, root bark, and root extracts. These extracts from distilled water is blue back and yellowish/orange colour from ethanol solvent systems. The qualitative test was carried out in each case.

\section{Test for Alkaloids}

About $0.2 \mathrm{~g}$ of ethanolic and $0.2 \mathrm{~g}$ of distilled water crude extract was warmed separately with $2 \% \mathrm{H}_{2} \mathrm{SO}_{4}$ for two minutes and filtered. From the filtrate, $1 \mathrm{ml}$ was taken individually into a test tube, and a few drops of Wagner's reagent added drop by drop. The formation of a reddish-brown precipitate indicated alkaloids in the tested parts of the plant (Gul et al., 2017; Lerato et al., 2017; François et al., 2020; Muhongo et al., 2021).

\section{Test for Saponins}

About one gram of ethanolic and $1 \mathrm{~g}$ of distilled water crude extract was boiled separately with $5 \mathrm{ml}$ of distilled water, and then it was filtered. To the filtrate, about $3 \mathrm{ml}$ of distilled water was further added and shaken vigorously for about 5 minutes. Frothing, which persisted on warming in each case, was taken as evidence for the presence of saponins (Gul et al., 2017; Lerato et al., 2017; François et al., 2020; Muhongo et al., 2021).

\section{Test for Phenolic Compounds}

The crude ethanolic and distilled water extract $(20 \mathrm{mg})$ was dissolved separately in $5 \mathrm{ml}$ of distilled water, and few drops of neutral $5 \%$ ferric chloride solution were added. A dark green color in each case was obtained and indicated phenolic compounds (Gul et al., 2017; Lerato et al., 2017; François et al., 2020; Muhongo et al., 2021).

\section{Test for Tannins}

About $0.2 \mathrm{~g}$ of crude ethanolic and $0.2 \mathrm{~g}$ of distilled water crude extract was stirred with about $10 \mathrm{ml}$ of distilled water separately, and then it was filtered. Few drops of $1 \%$ ferric chloride solution were added to 2 $\mathrm{ml}$ of the filtrate. The occurrence of a blue-black, green or blue-green precipitate indicated the presence of tannins (Gul et al., 2017; Lerato et al., 2017; François et al., 2020; Muhongo et al., 2021).

\section{Test for Flavonoids}


About $0.2 \mathrm{~g}$ of ethanolic crude extract was dissolved in water and filtered; to the filtrate, $2 \mathrm{ml}$ of the $10 \%$ aqueous sodium hydroxide was later added to produce a yellow coloration. A change in color from yellow to colorless on the addition of dilute hydrochloric acid was taken as evidence for the presence of flavonoids (Gul et al., 2017; Lerato et al., 2017; François et al., 2020; Muhongo et al., 2021).

\section{Test for steroids}

About $0.2 \mathrm{~g}$ of crude extract was taken and $2 \mathrm{ml}$ of acetic acid was added then, the solution was cooled well in ice followed by the addition of conc. $\mathrm{H}_{2} \mathrm{SO}_{4}$. Colour development from violet to blue or bluish-green indicated the presence of a steroidal ring (Gul et al., 2017; Lerato et al., 2017; François et al., 2020; Muhongo et al., 2021).

\section{Test for Quinones}

About $0.2 \mathrm{~g}$ of crude ethanolic extract was shaken with $10 \mathrm{ml}$ of benzene and then filtered. Then, five milliliters of the $10 \%$ ammonia solution were added to the filtrate, and after that, it was shaken. The appearance of pink, red, or violet color in the ammoniacal (lower) phase was taken as the presence of quinones (Gul et al., 2017; Lerato et al., 2017; François et al., 2020; Muhongo et al., 2021).

\section{Test for Carbohydrates}

About $2-3$ drops of a solution of lodine (I2) $0.02 \%$ and potassium iodide $(\mathrm{KI}) 0.6 \%$ were added to the sample. A light orange-brown color/deep blue obtained indicated the presence of starch.

\section{Test for protein}

Biuret test, $2 \mathrm{ml}$ (10 drops) of $5 \%$ sodium hydroxide solution was applied in to $2 \mathrm{ml}$ sample, and then after mixing, two drops of copper sulphate were added. The appearance of purple/ violet color observation indicated the presence of protein (Gul et al., 2017; Lerato et al., 2017; François et al., 2020; Muhongo et al., 2021).

\section{Test for fat/oil}

A small amount of the sample was wrapped with white paper and kept in sunlight to dry for a while. The oily patch observed on the paper indicated fat/oil (Gul et al., 2017; Lerato et al., 2017; François et al., 2020; Muhongo et al., 2021).

\section{Antibacterial Activity Using Extracts of M. oblongifolia}

. The procedure used for the preparation of samples was adapted from Eloff (CLSI, 2020). The extracts were dissolved in Dimethyl sulfoxide (DMSO) to prepare stock solutions at a concentration of $100 \%$. To be precise, took $99.9 \mathrm{ml}$ medium $+0.1 \mathrm{ml}$ DMSO because of toxicity, the volume fraction of DMSO is on the order of a few percent (Caroline et al., 2018). Fresh DMSO was used to ensure optimal solubility. 
The Makwar standard solution formula $\mathrm{M}_{1} \mathrm{~V}_{1}=\mathrm{M}_{2} \mathrm{~V}_{2}$, was used to determine the concentration of extracts and solvents. The four parts of ethanol and water extracts, total of eight stocks was prepared. The first $100 \%$ was used as stock; $100 \%=15 \mathrm{ml} ; 50 \%=20 \mathrm{ml} ; 25 \%=30 \mathrm{ml}$ and $12.5 \%=40 \mathrm{ml}$ were used in each case. The preparation of a petridish containing $15-25 \mathrm{~mL}$ agar, bacteria (E. coli and S. typhi) at a known concentration is then spread across the agar surface and allowed to establish. A $6 \mathrm{~mm}$ paper disk containing a known volume of the test substance is then placed in the center of the agar and the dish incubated for $24 \mathrm{~h}$. At this time the "cleared" zone (zone of inhibition) surrounding the disk was measured and compared with zones for standard antibiotics (Bacitracin 10 PK07 sensitivity disc). On the other hands, data from this assay is typically presented as mean size of zone of inhibition.

\section{Result}

\section{Preliminary Ethnobotanical Information}

Most of traditional medicinal practitioners realized that $M$. oblingifolia is one of the plants extensively used for traditional medicine. It was informed that its root is used to treat more than 13 diseases like diarrhea, stomachache, severe abdominal cramp, body swelling, mamp, tetanus, meningitis, eye disease, liver sirrhosis, gonorrhea, hook worm, and anthrax and for different disease of both human and cattle. They extract its constituents using water and "Harak'iya" (local alcohol). They also provided information that the plant was threatened because of its roots were targeted for different purposes including the extensive use as traditional medicine and detergent (local soap) by the community.

\section{Preliminary phytochemical screening of M. oblongifolia extract}

The biologically active crude extracts of leaves, roots, root barks and stem barks using the powder of the medicinal plant, $M$. oblongifolia, which had high fidelity level was exhaustively extracted with distilled water and ethanol at room temperature (Table 1). The yield also varied in color. The aqueous was suspended in the air of water bath (HWS-24volt220v/50HZ/Watts $1000 \mathrm{w}$ ) $60^{\circ} \mathrm{C}$ at room temperature to give $(13.1 \mathrm{~g}, 8.73 \%)$ Blueblack/brownish crude extract. The ethanol extract solution was filtered and concentrated by a vacuum rotary evaporator at $60{ }^{\circ} \mathrm{C}$ yielding Orange/yellowish crude extract $(16 \mathrm{~g}, 10.67$ $\%)$.

Table 1

Preliminary phytochemical screening of M. oblongifolia extract

\begin{tabular}{|lllllllll|}
\hline Code & MoLW & MoLE & MoSb LW & MoSb E & MoR W & MoR E & MoRb W & MoRb E \\
\hline \% yield & 6.6 & 9.07 & 8.73 & 10.67 & 5.8 & 2.93 & 2.1 & 7.8 \\
\hline * Note: $\mathrm{Mo}=$ M. oblongifolia; L = Leaf; $\mathrm{Sb}=$ Stem bark, Rb = Root bark; $\mathrm{R}=$ Root $;$ W = water; $E$ = ethanol \\
\hline
\end{tabular}

Phytochemical Analysis of Maerua oblongifolia Crude Extracts 
Preliminary phytochemical screening tests of the crude extracts were carried out to identify the classes of chemical constituents. The leaves, roots, root barks and stem barks ethanol and aqueous crude extracts of the powder of $M$. oblongifolia were subjected to various chemical testes to evaluate phytochemicals. The result revealed alkaloids, saponins, tannins, phenols, carbohydrates, and proteins in the extract of $M$. oblongifolia (Table 2).

Table 2

Reagents and their qualitative test on M. oblongifolia crude extracts

\begin{tabular}{|lllllllllll|}
\hline SN & $\begin{array}{l}\text { Class of } \\
\text { compounds }\end{array}$ & MoRb & \multicolumn{3}{l}{ MoR } & \multicolumn{3}{c|}{ MoSb } & \multicolumn{3}{c|}{ MoL } \\
\cline { 2 - 10 } & & Ethanol & Water & Ethanol & Water & Ethanol & Water & Ethanol & Water \\
\hline 1 & Alkaloid & ++ & + & + & ++ & ++ & ++ & ++ & ++ \\
\hline 2 & Tannins & ++ & + & ++ & ++ & + & + & ++ & ++ \\
\hline 3 & Saponins & ++ & ++ & ++ & + & ++ & ++ & ++ & ++ \\
\hline 4 & Flavinoids & ++ & + & + & - & - & - & - & - \\
\hline 5 & Terpnoids & - & - & - & - & - & + & - & + \\
\hline 6 & Steroids & - & - & - & - & - & - & - & + \\
\hline 7 & Quinines & - & + & - & - & - & - & - & - \\
\hline 8 & Phenols & ++ & ++ & ++ & + & ++ & ++ & ++ & ++ \\
\hline 9 & Carbohydrates & ++ & + & - & + & - & - & + & - \\
\hline 10 & Protein & + & ++ & + & + & - & - & - & + \\
\hline
\end{tabular}

\section{Antibacterial Activity}

Testing methods in detecting antimicrobial resistance record of the plant extract resulted for the two bacteria using control of the antibiotics (antimicrobial agent) discs to see the range of resistance (Table 3). 
Table 3

Disk Diffusion Zone Diameter Chart

\begin{tabular}{|c|c|c|c|c|c|c|c|c|}
\hline \multirow[t]{2}{*}{ Extract } & \multicolumn{4}{|l|}{ E. coli } & \multicolumn{4}{|l|}{ S. typhi } \\
\hline & $100 \%$ & $50 \%$ & $25 \%$ & $12.5 \%$ & $100 \%$ & $50 \%$ & $25 \%$ & $12.5 \%$ \\
\hline MoLW & $\begin{array}{l}10.0 \pm \\
1.00\end{array}$ & $\begin{array}{l}9.0 \pm \\
1.00\end{array}$ & $\begin{array}{l}7.3 \pm \\
0.58\end{array}$ & $\begin{array}{l}7.0 \pm \\
1.00\end{array}$ & $\begin{array}{l}8.7 \pm \\
1.15\end{array}$ & $\begin{array}{l}7.3 \pm \\
0.58\end{array}$ & $\begin{array}{l}6.3 \pm \\
0.58\end{array}$ & $\begin{array}{l}6.0 \pm \\
0.00\end{array}$ \\
\hline MoLE & $\begin{array}{l}14.7 \pm \\
0.58\end{array}$ & $\begin{array}{l}13.7 \pm \\
0.58\end{array}$ & $\begin{array}{l}12.0 \pm \\
1.00\end{array}$ & $\begin{array}{l}9.0 \pm \\
1.00\end{array}$ & $\begin{array}{l}12.0 \pm \\
1.00\end{array}$ & $\begin{array}{l}11.7 \pm \\
0.58\end{array}$ & $\begin{array}{l}9.7 \pm \\
0.58\end{array}$ & $\begin{array}{l}7.7 \pm \\
0.58\end{array}$ \\
\hline MoRW & $\begin{array}{l}12.3 \pm \\
2.08\end{array}$ & $\begin{array}{l}10.0 \pm \\
1.00\end{array}$ & $\begin{array}{l}7.3 \pm \\
0.58\end{array}$ & $\begin{array}{l}6.0 \pm \\
0.00\end{array}$ & $\begin{array}{l}9.3 \pm \\
0.58\end{array}$ & $\begin{array}{l}8.0 \pm \\
0.00\end{array}$ & $\begin{array}{l}7.3 \pm \\
0.58\end{array}$ & $\begin{array}{l}6.3 \pm \\
0.58\end{array}$ \\
\hline MoRE & $\begin{array}{l}19.7 \pm \\
1.15\end{array}$ & $\begin{array}{l}17.3 \pm \\
0.58\end{array}$ & $\begin{array}{l}14.3 \pm \\
2.08\end{array}$ & $\begin{array}{l}12.0 \pm \\
2.00\end{array}$ & $\begin{array}{l}19.3 \pm \\
0.58\end{array}$ & $\begin{array}{l}17.0 \pm \\
1.00\end{array}$ & $\begin{array}{l}13.0 \pm \\
1.00\end{array}$ & $\begin{array}{l}10.7 \pm \\
1.15\end{array}$ \\
\hline MoRbW & $\begin{array}{l}10.0 \pm \\
1.00\end{array}$ & $\begin{array}{l}9.0 \pm \\
1.00\end{array}$ & $\begin{array}{l}7.7 \pm \\
0.58\end{array}$ & $\begin{array}{l}6.0 \pm \\
0.00\end{array}$ & $\begin{array}{l}10.7 \pm \\
3.06\end{array}$ & $\begin{array}{l}8.3 \pm \\
1.53\end{array}$ & $\begin{array}{l}8.0 \pm \\
2.00\end{array}$ & $\begin{array}{l}7.3 \pm \\
1.53\end{array}$ \\
\hline MoRbE & $\begin{array}{l}13.3 \pm \\
4.93\end{array}$ & $\begin{array}{l}10.3 \pm \\
0.58\end{array}$ & $\begin{array}{l}9.3 \pm \\
1.15\end{array}$ & $\begin{array}{l}7.0 \pm \\
1.00\end{array}$ & $\begin{array}{l}10.3 \pm \\
0.58\end{array}$ & $\begin{array}{l}9.3 \pm \\
0.58\end{array}$ & $\begin{array}{l}7.7 \pm \\
0.58\end{array}$ & $\begin{array}{l}7.0 \pm \\
0.00\end{array}$ \\
\hline MoSbW & $\begin{array}{l}11.7 \pm \\
0.58\end{array}$ & $\begin{array}{l}9.7 \pm \\
1.15\end{array}$ & $\begin{array}{l}8.0 \pm \\
1.00\end{array}$ & $\begin{array}{l}6.3 \pm \\
0.58\end{array}$ & $\begin{array}{l}10.3 \pm \\
0.58\end{array}$ & $\begin{array}{l}9.7 \pm \\
1.15\end{array}$ & $\begin{array}{l}8.3 \pm \\
0.58\end{array}$ & $\begin{array}{l}8.0 \pm \\
0.00\end{array}$ \\
\hline MoSbE & $\begin{array}{l}17.0 \pm \\
1.00\end{array}$ & $\begin{array}{l}15.0 \pm \\
1.00\end{array}$ & $\begin{array}{l}14.0 \pm \\
1.00\end{array}$ & $\begin{array}{l}11.3 \pm \\
0.58\end{array}$ & $\begin{array}{l}17.0 \pm \\
1.00\end{array}$ & $\begin{array}{l}16.3 \pm \\
1.53\end{array}$ & $\begin{array}{l}14.0 \pm \\
1.00\end{array}$ & $\begin{array}{l}11.0 \pm \\
1.00\end{array}$ \\
\hline
\end{tabular}

\section{Discussion}

\section{Extraction through Maceration}

The percentage yield of crude extract was higher in ethanol and lower in aqueous solution. When a solvent is a weak solubilizer, there is a reduced dissolution which leads to higher mass (Muhongo et al., 2021). Organic compounds like terpinoid and steroid do not dissolve in aqueous solution; water dissolves polar compounds. In aqueous extract the weight of the product might increase. This might come from the presence of non-polar compounds. The results of total phytochemical contents exhibited in this plant with a very high concentration of total contents may be attributable to use of solvents based on polarity without combining those (Muhongo et al., 2021).

\section{Phytochemical Analysis of Maerua oblongifolia Crude Extracts}


There are different factors that might affect the quantity and composition of the phytocompounds present in an extract. Among these are genetic variation, the types of extraction, time of extraction, temperature, nature of the solvent, solvent concentration and lastly polarity of the solvent (Lerato et al., 2017). The constituent study has been done on different parts of the plant, M. oblongifolia. The studies (Sasi et al., 2020) showed that the roots contained alkaloids, carbohydrates, glycosides, phytosterols, saponins, proteins and amino acids. The phytoconstituents alkaloids, saponins, tanins and phenols were $100 \%$ both in aqueous and alcoholic extracts of the plant, and carbohydrate and protein to some extent which agrees with the study of Bhalakiya and Nainesh (2019). Most probably, it is thought that alkaloid in the root became effective in cases of aliment of some microbial diseases because alkaloids had been studied in modern medicine to validate their traditional use due to their pharmacological properties mainly for antibacterial activities (Muhongo et al., 2021). The distribution of this compound in all parts of the plant indicates the shifting hope (possibility) to use other parts of the plant rather than its root destructive use. No terpnoids, flavonoids, quinines and steroid compounds were found in both the aqueous and alcoholic extracts and this agrees with the study of Bhalakiya and Nainesh (2019). This may indicate the need for high polar solvents for extraction; otherwise the nature of plant may be without these constituents.

\section{Antibacterial Activity}

The antibacterial activity of the phytochemical compounds in the root, root bark, stem bark and leaf ethanol and aqueous solvents extracts of $M$. oblongifolia were checked using Bacitracin as a standard reference drug on $E$. coli and $S$. typhi. Testing methods in detecting antimicrobial resistance record of the plant extract resulted for the two bacteria using control of the antibiotics (antimicrobial agent) discs to see the range of resistance (Table 3). Antimicrobial property of plants indicates the presence of bioactive secondary metabolites (Bhalakiya and Nainesh, 2019). Its effectiveness was reported in gram-negative bacteria $E$. coli with largest zone of inhibition (Sasi et al., 2020). In this experimental study, the inhibition zone of ethanol extract root and stem bark of $M$. oblongifolia in diarrhea causing microbes, E.coli is 10 $21 \mathrm{~mm}(19.7 \pm 1.15$ and $17 \pm 1.0$ in root and stem bark respectively) and $S$. typhi 10-18mm (19.3 \pm 0.58 and $17 \pm 1.0$ in root and stem bark respectively) in diameter. Ethanol and water extracts appeared better for application compared to the chloroform and methanol extracts (Ehssan et al., 2012) for inhibition of $E$. coli and $S$. typhi at 15 and $14 \mathrm{~mm}$ radius respectively.

The study also showed that these plant parts may be good quality as an antibacterial (Bhalakiya and Nainesh, 2019). Because, the zone of inhibition ranging from 13-20 mm indicates that the extract had inhibitory activity against most of the organism (Sasi et al., 2020). Therefore, this indicates that (1) The ethanolic root and stem bark extracts of $M$. oblongifolia are effective in treatment of diarrhea (inhibiting $E$. coli and S. typhi), (2) the possibility of using stem bark instead of using root (more or less similar diameter in both extracts) for treatments of aliments and (3) the presence of bioactive compounds in different parts of the plant. The trend of using root rather than other parts in community because of acquiring from fore-practitioners and the opportunity of getting the resource for other services like detergent and good smell. 
Phytochemical compounds are determined as secondary metabolites that pose various properties including antimicrobials, antioxidants, antiviral and many more (Muhongo et al., 2021). The extracts derived from ethanol were more active than aqueous extracts. This may indicate that the non-polar active principles are responsible for the antimicrobial activity in M. oblongifolia (Bhalakiya and Nainesh, 2019). Alkaloids have been extensively researched because of their biological activity and medicinal uses (Thawabteh et al., 2019). The higher level of alkaloids indicates its significance and application in treatment of a broad range of infectious diseases (Muhongo et al., 2021). Therefore, though isolation and characterization are yet not done, from qualitative testing and from literature sources, it is projected that the alkaloids in this plant might be bioactive compounds that may result in its effectiveness shown by inhibition of the microbes tested.

The phytocompounds present in Maerua oblongifolia are a potential source of chemotherapeutic compounds. In this study, the root and stem bark were found to contain the most phytocompounds validating their traditional use in the treatment of various ailments such as diarrhea and other bacterial infections. The findings over and above supporting the traditional use of the plant for the treatment of diarrhea, favored the hypothesis that shifting from the traditional use of the root to that of the stem bark through sustainable harvesting to ensure conservation and sustainable use of the species. This study can also be applied to other traditional medicinal plants in which the species are threatened due to unsustainable use of more sensitive plant parts by shifting to less sensitive parts after checking the effectiveness. Further research is, however, required to optimize the biomedical applications of the plant. The two solvents used in this study were able to extract different bioactive compounds and this constitutes vital information for those wishing to extract compounds from the plant for further research as their presence was observed in all the plant parts to isolate, identify, characterize, and elucidate the structure of these bioactive compounds. The use of different solvents may also be considered as solvents are selective for the extraction of specific compounds.

The results from this study demonstrate that $M$. oblingfolia root and stem barks have abundant secondary metabolites which are largely utilized in traditional medicine to combat and cure numerous infections including diarrhea. Qualitative and quantitative analysis indicates that the M. oblingfolia root and stem barks are potential sources of phytochemicals that could be used in drug discovery and development. Ethanol solvent extraction yields maximum phytochemical compared to the other solvents and therefore recommended for the extraction of plant material from this species.

The antibacterial testing of the $M$. oblingfolia root and stem barks extracts ensured the inhibition potential of diarrhea-causing bacteria. However, further confirmatory studies followed by isolation and characterization of the active antimicrobial compound (s) of the plant that are responsible for the observed microbial suppression is needed before it is recommended for diarrhea drug search and discovery. Since, both parts do have potential of inhibition; it has possibility of using stem barks instead of root of the plant to avoid threatening condition of traditional harvest.

\section{Conclusion}


Maerua oblongifolia is being overexploited and is in danger of becoming extinct in local level due to root harvesting for different purposes. In this case, since the bioactive extracts from the root and stem barks of the plant were tested and confirmed based on the ethnobotanical leads, extraction and application to treat diarrhea, this information will have practical application in conserving the species and facilitating continued sustainable utilization. That is since most of the bioactive compounds present in the root are also found in the stem bark in sufficient quantities, it is possible to harvest ascertain sector of the stem bark while leaving the other sector and other parts, especially the underground part (root and root barks) of the plant intact to regenerate itself.

Finally, vitality works that can save those threatened plants with medicinal use through assessing indigenous knowledge about the use and status of medicinal plants before the knowledgeable people leave or die combining it with ethnobotanical knowledge-led composition analysis and antibacterial testing is a better strategy to conserve threatened medicinal plants. This must be followed by awareness raising mainly targeted to traditional medicinal plants practitioners to shift the plant part they use those known to be less destructive and suited to sustainable harvesting thereby ensuring continued use and conservation of the target plant species.

\section{Declarations}

\section{Ethics approval and consent to participate}

"Not applicable".

\section{Consent for publication}

"Not applicable".

\section{Availability of data and materials}

“Not applicable.

\section{Competing interests}

"The authors declare that they have no competing interests".

\section{Funding}

Araba Minch University (AMU) was acknowledged for financial support through code GOV/AMU/TH2/CNS/Bio/06/2012.

\section{Authors' contributions}

Mathewos Agize Ante conceived and designed the study; collected specimen, performed the experiments; analyzed the data and written the draft of manuscript. Zemede Asfaw WoldeMariam, Sileshi Nemomissa 
Duguma, and Tizazu Gebre Alemayehu helped to design the study and supervised the study, and edited the manuscript. Mathewos Anza Alemu helped to perform phytochemical analysis study and edited the manuscript. Tizita Lema Bargene and Mintiwab Abrham Dana helped to perform antibacterial testing study. All authors read and approved the final manuscript.

\section{Acknowledgements}

The authors are grateful for ethnobotanical information provision, plant material collection, guiding and supporting in ragged topography journey by local people. The authors are thankful for the financial support provided by Araba Minch University (AMU). They also would like to thank the staff of Departments of Biotechnology, Biology, Chemistry and Pharmacy in Wolaita Sodo University for their support of materials, chemicals and allowed to use their laboratory for experimental study and for their assistance during the study. Finally, Addis Ababa University for allowing National Herbarium for their kind permission to use for identification processes.

\section{References}

1. Agize M., Demissew S., and Asfaw Z. (2013). Ethnobotany of Medicinal Plants in Loma and Gena Bosa Districts (Woredas) of Dawro Zone, Southern Ethiopia. Topclass Journal of Herbal Medicine Vol. 2(9): 194-212.

2. Arulanand R.N., Gopal V., Dhivya S., Jayabalan G. (2018) "Evaluation of wound healing effect of Maerua Oblongifolia in albino rats". World J Pharma Res 8 (1):1380-1385.

3. Bhalakiya H.L. and Nainesh R.M. (2019). A Comprehensive Review on Maerua Oblongifolia (Forsk.) A. Rich. International Journal of Research in Advent Technology, 7 (4) 721-727.

4. Caroline S., Stéphane D., Christiane C.P., Wladimir U., Patrick F., Fuchs J., and Nicolas T. (2018). Effect of Dimethyl Sulfoxide on the Binding of 1-Adamantane Carboxylic Acid to $\beta$ - and $y$-Cyclodextrins. Amercan Chemical Society, ACS Omega. 3(1): 1014-1021.

5. Clinical and Laboratory Standards Institute (CLSI).(2020).Performance Standards for Antimicrobial Susceptibility Testing. 30th ed. CLSI supplement M100 (ISBN 978-1-68440-066-9 [Print]; ISBN 978-168440-067-6 [Electronic]). Clinical and Laboratory Standards Institute (CLSI), 950 West Valley Road, Suite 2500, Wayne, Pennsylvania 19087 USA.Pp.294.

6. Cochran, W.G. (1963). Sampling Techniques, Wiley, New York.

7. Cotton, C. M. (1996). Ethno botany. Principle and Application. Chi Chester New York.

8. Ehssan H.o M., Muddathir S. A., Koko W.S. and Saadabi A.M. (2012). In vitro Antimicrobial Activity of Sudanese Medicinal Plants. J.Med.Sci., 12(7):219-223.

9. Ekero D., Legesse M., Lelago A. and Agize M. (2018). Extraction, Isolation and Characterization of Maerua oblongifolia ('Sanagana'). International Journal of Current Research in Biosciences and Plant Biology 5(3), 42-48.

10. François N., Charity N.M., Fred O., Mery C., Nicholas A., Jones O. M. and Elizabeth M. K. (2020). Antimycobacterial activities, cytotoxicity and phytochemical screening of extracts for three medicinal 
plants growing in Kenya. Journal of Medicinal PlantsResearch, 14(4): 129-143.

11. Gul R., Umer J., Syed F., Syed S.S. and Jahan N. (2017). Preliminary Phytochemical Screening, Quantitative Analysis of Alkaloids, and Antioxidant Activity ofCrude Plant Extracts from Ephedra intermedia Indigenous to Balochistan. The Scientific World Journal. Volume 2017, Article ID 5873648, 7 pageshttps://doi.org/10.1155/2017/5873648

12. InsightSLICE (2021). Herbal Medicine Market Global Sales. https://www.sahyadritimes.com. February 16, 2021 07:49 ET | Source: insightSLICE.

13. Kuria, A., Dawit, S., Endale, Y., Derero, A., liyama, M., Muthuri, C., Hadgu, K., Kinuthia, R., Betemariam, E., Asantewaa, M., Muriuki, J., Kindt, R., Dedefo, K., Senbeto, M., Njenga, M., Lamond, G., Pagella, T., \& Sinclair, F. (2017). Suitable tree species selection and management tool for Ethiopia. [Database], World Agroforestry Centre (ICRAF). http://apps.worldagroforestry.org/

14. Lerato N.M., Samkeliso T., Michael P. (2017). Preliminary Phytochemical Screening of Crude Extracts from the Leaves, Stems, and Roots of Tulbaghia violacea. International Journal of Pharmacognosy and Phytochemical Research; 9(10): 1300-1308.

15. Martin, G. J. (1995). Ethnobotany. A method manual. World wide fund for Nature, Chapman and Hall, London.

16. Meragiaw M. (2016). "Wild useful plants with emphasis on traditional use of medicinal and edible plants by the people of Aba'ala, North-eastern Ethiopia." J Med Plant Herb Ther Res 4 (1): 1-16.

17. Mohamed I.E.T. and Abdelrahman M.E.N. (2010). "The antibacterial, antiviral activities and phytochemical screening of some Sudanese medicinal plants." EurAsian Journal of BioSciences 4 (1): 8-16.

18. Muhongo M.N., Kangogo M. and Bii C. (2021). Qualitative and quantitative phytochemical profiling of crude fractions of Pechuel-Loeschea leubnitziae leaves . Journal of Medicinal Plants Research 15(2):64-72.

19. Raju,Y., Ratna P., UgandharY. and Savithramma N. (2014). "Documentation of ethnomedicinal knowledge of hilly tract areas of east Godavri district of Andhra Pradesh, India." Int J Pharm Pharm Sci 6: 369-374.

20. Reddy S., Rajagopal A., Madhusudhana R., and Suresh B.M.V. (2015). "Traditional Medicinal Plants of Lankamalleswara Wildlife Sanctuary, Kadapa District, Andhra Pradesh, India." American Journal of Ethnomedicine 2 (6): 2348-9502.

21. Revolvy L. (2019). "Maerua oblongifolia" on Revolvy.com. [Online]: Available at: https://www.revolvy.com/page/Maerua-oblongifolia.

22. Santosh P. (2019): Root of relief. [Online] Telangana Today. Available at: https://telanganatoday.com/root-of-relief.

23. Sasi Priya S.V.S., Ranjitha M.U., Nithyashree R.S., Shouvik K.D., Tanmoy G., Sundara Saravanan K. Mohammad A (2020). Maerua oblongifolia - What do we really know? Overview, Progress and Perspectives. Journal of Peer Scientist 2(1): 1-7. 
24. Savithramma N., Linga R.M. and Suhrulatha D. (2011). Screening of Medicinal Plants for Secondary Metabolites. Middle-East Journal of Scientific Research 8 (3): 579-584.

25. Savithramma N., Yugandhar P., Prasad K., Ankanna S., Chetty K., Savithramma N. (2016). "Ethnomedicinal studies on plants used by Yanadi tribe of Chandragiri reserve forest area, Chittoor district, Andhra Pradesh, India." Journal of intercultural ethnopharmacology 5 (1): 49-53.

26. Shodhganga (2019).inflibnet.ac.in. [online]: Available at: https://shodhganga.inflibnet.ac.in /bitstream/10603/61112/7/07_chapter\%201.pdf.

27. Thawabteh A., Juma S., Bader M., Karaman D., Scrano L., Sabino A. and Karaman R. (2019). The Biological Activity of Natural Alkaloids against Herbivores, Cancerous Cells and Pathogens. Toxins 11: 656; doi:10.3390/toxins11110656 www.mdpi.com/journal/toxins P1-28. 